\title{
Dyslexia in the context of second language learning and teaching
}

\section{JoANNA NiJAKowSKa}

University College of English Language Teacher Education

University of Warsaw

Nowy Świat 4

00-497 Warsaw, Poland

E-mail: j.nijakowska@uw.edu.pl

\section{DYSLEXIA IN THE CONTEXT OF SECOND LANGUAGE LEARNING AND TEACHING}

\begin{abstract}
The paper elucidates the complex nature of dyslexia, specifying the multiple levels of explanation of this phenomenon and indicating the causal relations between them. It defines dyslexia, sketches the way it surfaces across languages, identifies the overlaps between the native and second/foreign language learning, and outlines the potential difficulties that dyslexic learners may encounter in second language learning. Finally, research referring to foreign language teachers' preparedness to include dyslexic learners in mainstream classes is discussed. An account of the components of teacher preparedness is provided, including background knowledge on dyslexia, self-efficacy beliefs about implementing inclusive instructiona practices, and attitudes towards inclusion, which can be subject to change as a result of professional training. The paper stresses the pressing needs for the provision of appropriate and sufficient initial teacher training and continuing professional development opportunities for foreign language teachers in order to prepare them to appropriately recognize and respond to dyslexic foreign language learners needs.
\end{abstract}

KEY WORDS: dyslexia; foreign language; teacher preparedness; teacher training; inclusion.

SUMMARY: 1. Nature of dyslexia (1.1. Levels of explanation, 1.2. Defining dyslexia). 2. Dyslexia and second language learning. 3. Foreign Language Teacher Preparedness to Include Dyslexic Learners (TEPID)

DISLEXIA EN LA ENSEÑANZA Y EN EL APRENDIZAJE DE UNA SEGUNDA LENGUA

RESUMEN: El presente artículo gira en torno a la complejidad de la dislexia, especificando los múltiples niveles de explicación de dicho fenómeno e indicando las posibles relaciones causales entre ellos. Se define la dislexia y se explica cómo se manifiesta en distintas lenguas, identificando semejanzas y diferencias en el aprendizaje de la lengua materna y de una segunda lengua/una lengua extranjera. Además, se presentan los potenciales obstáculos con los que se pueden encontrar los estudiantes con dislexia al aprender una segunda lengua. Por último, se analizan distintas investigaciones sobre la formación profesional del profesorado que enseña lenguas extranjeras a estudiantes disléxicos. En el artículo se comentan los componentes de una adecuada preparación docente, entre los que se incluyen el conocimiento sobre la dislexia, el convencimiento sobre la propia eficacia en la implementación de técnicas de educación inclusiva y en la actitud hacia la inclusión, las cuales pueden modificarse como re sultado de la formación y el perfeccionamiento profesional. El autor destaca la necesidad de asegurar una formación docente apropiada y un desarrollo profesional continuo a los profesores de lenguas extranjeras para que sean capaces de reconocer correctamente y reaccionar ante las necesidades de los estudiantes disléxi$\cos$

PALABRAS CLAVES: dislexia, lengua extranjera, preparación del profesorado para trabajar con estudiantes disléxicos, formación profesional del profesorado, educación inclusiva.

SUMARIO: 1. Características de la dislexia (1.1. Niveles de explicación, 1.2. Definición de dislexia). 2. Dislexia y adquisición de una lengua extranjera. 3. Forma ción profesional del profesorado de lenguas extranjeras para la educación inclusiva.

\section{LA DYSLEXIE DANS LE CONTEXTE DE L'APPRENTISSAGE ET DE L'ENSEIGNEMENT D'UNE LANGUE SECONDE}

RÉSUMÉ: Le but de cet article est d'élucider la nature complexe de la dyslexie, en spécifiant les multiples niveaux d'explication de ce phénomène et en indiquant les relations causales qu'ils entretiennent entre eux. Dans cet écrit, on définit la dyslexie, on esquisse la manière dont elle se présente à travers les langues, on identifie les chevauchements entre l'apprentissage d'une langue maternelle et celui d'une langue seconde / étrangère et on décrit les difficultés que les apprenants dyslexiques peuvent rencontrer lors de l'apprentissage d'une langue seconde. Enfin, on se penche sur les recherches se rapportant à la formation des enseignants de langues étrangères afin qu'ils soient à même d'inclure les apprenants dyslexiques dans leurs classes. L'article offre aussi un aperçu synthétique des composantes de la préparation des enseignants, comprenant les connaissances de base sur la dyslexie, les convictions relatives à l'efficacité personnelle dans la mise en œuvre de pratiques d'enseignement inclusif et les attitudes à l'égard de l'inclusion, qui peuvent être modifiées à la suite d'une formation professionnelle. Le texte souligne la nécessité pressante de fournir aux enseignants de langues étrangères une formation initiale appropriée ainsi que des possibilités de développement professionnel continu afin de les former à reconnaître les besoins des apprenants dyslexiques et à y répondre de façon appropriée.

MOTS CLÉS: dyslexie, langue étrangère, TEPID, formation des enseignants, inclusion.

SOMMAIRE: 1. Nature de la dyslexie (1.1. Niveaux d'explication, 1.2 Définition de la dyslexie). 2. Dyslexie et apprentissage d'une langue seconde. 3. TEPID. $\begin{array}{ll}\text { Fecha de Recepción } & 05 / 02 / 2019 \\ \text { Fecha de Revisión } & 08 / 03 / 2019 \\ \text { Fecha de Aceptación } & 10 / 05 / 2019 \\ \text { Fecha de Publicación } & 01 / 12 / 2020\end{array}$ 


\title{
Dyslexia in the context of second language learning and teaching
}

\author{
JOANNA NIJAKOWSKA
}

\section{NATURE OF DYSLEXIA}

\subsection{LEVELS OF EXPLANATION}

Dyslexia has neurobiological and genetic traces. It is one of the most intensively investigated and best-known developmental cognitive disorders that has been the point of interest for a number of scientific disciplines, including education, psychology, neurobiology and genetic studies. The complex, multifaceted nature of dyslexia forces description and explanation on multiple levels - biological, cognitive, and behavioural, with environmental influences operating at each of them (Frith, 1999).

Explanations of dyslexia at the biological level identify the underlying brain mechanisms (e.g. disorganisation in the cerebral cortex in the language areas, abnormal magnocellular pathways or abnormal cerebellum), while descriptions at the cognitive level relate to mind and mental processes looking at phenomena such as reduced working memory, poor phonological processing, incomplete automatization, and slow central processing. Finally, the behavioural level specifies manifestations of dyslexia (e.g. poor reading and spelling, difficulty with rhymes, poor motion sensitivity, poor rapid auditory processing and difficulty maintaining balance). Different theories of dyslexia are instantiated by different levels of explanation. The magnocellular deficit hypothesis or the cerebellar deficit hypothesis for example operate at the brain-based level, while the double deficit hypothesis and the automatization deficit hypothesis, along with a dominant hypothesis in dyslexia research - phonological deficit hypothesis are the cognitive level hypotheses (Nicolson, 2001).

The direction of the hypothesised causal links between the levels of explanation of dyslexia is both from the biological through the cognitive to the behavioural levels and backwards, however causality should be treated more as probability rather than certainty. Environmental impacts involving learning and experience are powerful enough to modify connections between nerve cells resulting in long-lasting structural and functional changes in the brain. Importantly, environment in which the development takes place is capable of altering gene expression as a result of its interaction with genetic inputs, in that way influencing subsequent learning processes (Frith, 1999). For instance, the structural and functional anomalies in dyslexics' left perisylvian areas (traditionally associated with language), triggered to a certain degree by genetic influence (biological level), are believed to cause the phonological deficit (cognitive level), which is in turn responsible for dyslexic reading difficulties (behavioural level). The environmental factors such as 
reading-related activities, reading experience and instructional practices as well as the orthography (deep vs transparent) of a language being learned may modify the signs of dyslexia. Phonological awareness and letter knowledge training can lessen dyslexic reading difficulties (behavioural level). Reading intervention programmes may also result in altered activation patterns in particular left hemisphere brain systems involved in language and reading (biological level) (Ramus, 2004, 2006; Vellutino et al., 2004).

Current knowledge of dyslexia embraces multiple etiological conceptions and theories (e.g. Elliot and Grigorenko, 2014; Fawcett and Nicolson, 2004; Nicolson and Fawcett, 2008; Ramus et al., 2003, 2006), which trigger investigations producing a huge bulk of outcomes. These research findings, however, frequently provide inconsistent, debatable, if not conflicting research evidence (Elliott and Gibbs, 2008; Elliott and Grigorenko, 2014; Ramus, 2014). Complex neurobiological and cognitive patterns in dyslexia have been identified but they await further research, confirmation and integration. A comprehensive and coherent causal theory of dyslexia addressing all three levels of explanation, indicating the possible causal links between these separate levels of explanation and offering a single explanatory framework embracing a growing body of scientific evidence remains a future endeavour (Nicolson, 2001).

\subsection{DEFINING DYSLEXIA}

Dyslexia is one of specific learning difficulties. It is perceived as a type of disability and denoted with different terms across professional and geographical contexts depending on the perception and model of disability they adhere to, for instance the labels learning disability or learning disorder (e.g. the Diagnostic and Statistical Manual of Mental Disorders - DSM-5 classifies dyslexia as a learning disorder, APA, 2013) reflect a medical (deficit) model perspective, while the term learning difficulty essentializes an interactional model of a disability (e.g. Norwich, 2009). The later model stresses that educational interventions should be tailored to individual student's strengths and weaknesses. The term learning difficulty indicates that the skills must be learned, while specific implies that difficulties are restricted to problems with just one or a limited number of skills - academic skills of reading and spelling in the case of dyslexia.

Dyslexic individuals score poorly on standardised reading tests - quantifiably below what is expected for their age, despite adequate instruction and lack of visual or auditory acuity problems. These problems seem unexpected because other aspects of development and performance in other skills remain rather typical. Early signs of dyslexia can be observed in preschool but reliable diagnosis can be conducted after formal education begins. Dyslexia is a cross-cultural, chronic, lifetime condition which cannot be outgrown and typically persists into adulthood. The way dyslexia manifests itself depends significantly on the language being learnt and undergoes dynamic 
changes induced by other environmental factors such as education, reading experience, effectiveness of special interventions and classroom teaching methods. Its observable signs (symptoms) differ across individuals (Nijakowska, 2016). Children with dyslexia experience reading (decoding) difficulties of varying degrees but their reading and spelling tends to be much less skilful and proficient than would be expected of individuals at a given age. Dyslexia is viewed as a dimensional rather than a categorical phenomenon and as a delay in reading and spelling development (Hulme and Snowling, 2009; Snowling and Hulme, 2012).

Dyslexia is typically associated with phonological processing problems. Two contemporary and widely-accepted definitions include reference to the phonological deficit hypothesis. One of them is a working definition proposed by Rose (2009: 10):

Dyslexia is a learning difficulty that primarily affects the skills involved in accurate and fluent word reading and spelling. Characteristic features of dyslexia are difficulties in phonological awareness, verbal memory and verbal processing speed. Dyslexia occurs across the range of intellectual abilities. It is best thought of as a continuum, not a distinct category, and there are no clear cut-off points. Co-occurring difficulties may be seen in aspects of language, motor co-ordination, mental calculation, concentration and personal organisation, but these are not, by themselves, markers of dyslexia.

Another one is the definition of the US National Institute of Child Health (2002), adopted by the Board of Directors International Dyslexia Association (IDA), which states that:

Dyslexia is a specific learning disability that is neurobiological in origin. It is characterized by difficulties with accurate and/or fluent word recognition and by poor spelling and decoding abilities. These difficulties typically result from a deficit in the phonological component of language that is often unexpected in relation to other cognitive abilities and the provision of effective classroom instruction. Secondary consequences may include problems in reading comprehension and reduced reading experience that can impede growth of vocabulary and background knowledge.

Phonological processing problems are responsible for persistent belowstandard print processing involving inaccurate and/or non-fluent and slow decoding (reading) as well as incorrect encoding (spelling), which can cause dyslexic readers to lag behind their peers in literacy development. Impaired (late or incomplete) phonological processing and poor word decoding is reflected in a slow rate and low accuracy of reading, as best evidenced by results in single word and non-word (pseudo-word) reading tasks. Poor reading fluency and spelling ability in dyslexia often remain resistant to educational intervention, however, reading accuracy may reach reasonable levels provided appropriate instruction is available (Hulme and Snowling, 2009).

One of the most impactful environmental factor regulating the way dyslexia manifests itself is the orthographic system of a language being learnt. As evidenced in a number of cross-language studies, the speed and ease with which the word-level accuracy and fluency skills develop depends on 
the transparency of the orthographic system of a language in which a child is learning to read (Landerl et al., 2013; Moll et al., 2014; Seymour et al., 2003). For both dyslexic and non-dyslexic learners learning to read in a language with a more transparent orthography - with high degree of consistency in mapping letters onto sounds (e.g. Greek, Italian, Spanish) proves easier than learning to read in a language with a more opaque orthography (e.g. English) (Ziegler and Goswami, 2005, 2006; Ziegler et al., 2003). Dyslexic reading difficulties tend to be less severe in languages with more transparent orthographies (de Jong and van der Leij, 2003; Goswami, 2000; Miles, 2000). Dyslexic phonological processing problems are easier to grasp and usually more pronounced in deeper orthographic systems (Snowling, 2001; Vellutino et al., 2004).

\section{DYSLEXIA AND SECOND LANGUAGE LEARNING}

Dyslexia leaves its imprint not only on the development of learner's first language (L1) skills, but can also influence the acquisition of additional languages. Therefore, in order to satisfy the special educational needs of dyslexic individuals learning a second language (L2) and to employ effective instructional programmes, it is essential to understand how these learners develop their L2 (Kormos, 2017) and, consequently, how to train teachers so that they can appropriately respond to the L2 dyslexic learners' needs (Nijakowska, 2019). Language teaching pedagogy and second language acquisition (SLA) research extensively covered the area of individual learner differences but investigations into the role and impact of specific learning difficulties (learning disabilities) on additional language learning remain rather scarce (Kormos, 2017a, 2017b; Nijakowska, 2010; Sparks, 2013).

The Linguistic Coding Differences Hypothesis (LCDH) (Sparks and Ganschow, 1993) proposes that L1 and L2 are interdependent and that success in L2 learning largely relies on the L1 skills developed prior to exposure to L2. It assumes that L1 skills form the foundation for L2 learning, problems with one of the L1 components, for instance phonological processing, will affect both L1 and L2. The LCDH also asserts that the differences between students' L2 proficiency and classroom achievement result from individual subcomponents of language aptitude (Sparks et al., 1989). Research findings (Sparks, 2013) confirm the existence of strong relation between the early levels in L1 skills, especially L1 literacy and L2 aptitude and proficiency. The LCDH is consistent with the Common underlying cognitive processes framework (Geva and Ryan, 1993) indicating that individual differences in the underlying cognitive processes (working memory, phonological short-term memory, phonological awareness and RAN) can explain the correlations between L1 and L2 relating to similar language and literacy skills and predict word-reading skills, spelling, and reading fluency cross-linguistically. Assessment of these underlying cognitive factors does not require high levels of oral language proficiency and exposure and thus can prove 
highly useful and informative in the case of the learners with limited L2 oral language proficiency (Genesee et al., 2006; Geva and Wiener, 2015).

Skilful word recognition requires well developed phonological processing skills across languages. These skills in one language, no matter whether first (L1) or second/foreign language (L2) can predict individual differences in word decoding within and across these languages, even when oral proficiency is not yet fully developed in the L2 (Geva, 2000). Phonological processing difficulties responsible for dyslexic word-level decoding problems in L1 may affect the acquisition of the reading and spelling skills in L2. This knowledge is critical in bilingual and multilingual settings. Diagnosing dyslexia in children from ethnic and linguistic minorities, who use their L1 at home and L2 at school, poses considerable problems. These learners may not have a formal diagnosis of dyslexia in their L1, while their L2 literacy acquisition difficulties tend to be explained by their teachers by the lack of sufficient oral proficiency in the language of schooling (L2) or by cultural differences. Consequently, dyslexia in L2 may go unnoticed in these learners (Geva and Wiener, 2015).

Learners already diagnosed as dyslexic in their L1 who attempt to learn a foreign language may experience difficulties of varying degrees in acquiring literacy skills. Since the command of L2 is built upon the strength of L1 skills, the L2 literacy attainments of dyslexic learners may be expected to be inhibited, while learners who possess strong L1 skills are potentially better equipped to achieve high in L2 learning. Foreign language ability, similarly to reading ability, should be represented on a continuum. Many individuals with dyslexia learning L2 would probably occupy the more severe end of the continuum of L2 learning difficulties. Some of them, despite the progress they make, will still slightly lag behind their non-dyslexic peers in L2 learning (Ganschow and Sparks, 2001; Sparks et al., 2006). There is accumulating evidence confirming that dyslexic learners experience difficulties of varying severity in learning L2 and L2 literacy skills both in instructed classroom and immersion settings (Schneider and Crombie, 2003; Kormos, 2017a, 2017b; Peer and Reid, 2016). However, there exists considerable variation in L2 learning and attainment among dyslexic learners, with some of them outperforming their non-dyslexic peers on certain tasks in learning L2 or L1 (Helland and Kaasa, 2005; Miller-Guron and Lundberg, 2000; Palladino et al., 2013; Siegel, 2016; Sparks et al., 2008). Dyslexic learners' L2 learning and performance in the L2 classroom can be further diversified (boosted or inhibited) by the affective and cognitive factors as well as dynamically interacting environmental influences (Kormos, 2017b).

Research on dyslexia (and other SpLDs) in the field of second language acquisition (SLA) and language teaching followed a deficit view as well as an interactional view of learning disabilities (Norwich, 2009). The former sees learning difficulties as a deficit which requires educational interventions in a form of special accommodations offered in the classroom in order to meet 
individual special educational needs (SEN) of learners with dyslexia, the latter perceives an individual learning difficulty as interacting with the environmental obstacles and in that way impeding full participation in society. Studies adopting an interactional view of learning disabilities are still rare. To date research on dyslexia and second language acquisition has covered the cognitive and affective impact of dyslexia on second language learning processes (e.g. Csizér et al., 2010; Kormos and Csizér, 2010; Kormos et al., 2009; Piechurska-Kuciel, 2008; Sparks, 2013), foreign language teaching practices with dyslexic students and effectiveness of instructional programmes designed especially for dyslexic learners (e.g. Košak-Babuder et al., 2019; Nijakowska, 2008; Pfenninger, 2015), identification of dyslexia in multilingual speakers (Geva and Wiener, 2015; Martin, 2013) and assessment of the L2 skills of dyslexic learners (Tsagari and Spanoudis, 2013; Tsagari and Sperling, 2017) as well as L2 teacher knowledge and training (Kormos and Nijakowska, 2017; Nijakowska, 2014; Nijakowska and Kormos, 2016).

\section{Foreign Language Teacher PReparedness to INClude DySleXic LearN- ERS (TEPID)}

Foreign language teacher preparedness to successfully include dyslexic learners in mainstream classrooms is composed of two underlying factors, namely 1) teachers' beliefs about their possessed knowledge of dyslexia and their self-efficacy concerning inclusive instruction-related teacher classroom behaviour towards dyslexic learners (knowledge and skills) and 2) beliefs about inclusion of dyslexic learners in mainstream classrooms in general (attitude/stance). The analysis of the influence of a number of demographic variables on TEPID showed that the overall teaching experience and completed level of education (degree) do not alter TEPID levels in a statistically significant way, while variables such as country, level of training (pre-service vs. in-service), type of schooling situation/school teachers work at, and type of experience in teaching dyslexic students have effect on TEPID. Importantly, FL teachers who have more individualised and personalised teaching experience with dyslexic learners report higher levels of TEPID (Nijakowska et al., 2018).

FL teacher knowledge of the nature of dyslexia as a specific learning difficulty, its influence on L2 study, effective teaching techniques and inclusive instructional practices, and the underlying theoretical principles of effective reading intervention programmes as well as of the local educational policy and available classroom and exams accommodations constitutes an important component of teachers' preparedness to effectively work with dyslexic students in FL classrooms (Nijakowska et al., 2018). Teacher background language-based content knowledge, required to understand the nature of dyslexic language learning problems and principles of effective teach- 
ing approaches, involves knowledge of language and literacy concepts, explicit reading instruction principles, phonological awareness, orthographic awareness, and phonics (e.g. Brady et al., 2009; McCutchen et al., 2002, 2009; Podhajski et al., 2009). The more knowledgeable teachers are in the abovementioned areas the more self-confident they are in creating and working in inclusive contexts and in providing dyslexic FL learners with instruction appropriately adjusted to their educational needs and abilities (Aladwani and Al Shaye, 2012; Moats 2009; Moats and Foorman, 2003; Washburn et al., 2011a, 2011b).

FL teachers admit they have limited knowledge and understanding of the nature of dyslexic language learning difficulties, that they are ill-equipped to cater for the needs of these students and that they were not and are still not offered enough training in this area. Importantly, FL teachers also report that they are very much interested and willing to undertake adequate inservice training (Smith, 2008; Nijakowska, 2014). Insufficient and/or inadequate initial and in-service teacher training are frequently listed as possible causes of limited teacher knowledge in the abovementioned areas (Goldfus, 2012; Joshi et al., 2009; Nijakowska, 2014). At the same time, there is ample evidence that adequate professional teacher training can effectively and substantially increase teacher background knowledge (e.g. Goldfus, 2012; Kahn-Horwitz, 2015, 2016; Kormos and Nijakowska, 2017), teacher self-efficacy in using inclusive instructional practices, and attitudes as well as decrease concerns about inclusion (e.g. Chao et al., 2016; Florian, 2012; Forlin et al., 2014; Kormos and Nijakowska, 2017; Peebles and Mondaglio, 2014; Sharma and Sokal, 2015).

Teacher self-efficacy beliefs are teachers' assessment of their perceived competence and ability to perform in the classroom so that their instructional behaviour can trigger desired student behaviour and learning (Tschannen-Moran and Woolfolk Hoy, 2001, 2007). Teacher self-efficacy is context and task specific (Savolainen et al., 2012; Sharma and George, 2016; Tschannen-Moran and Woolfolk Hoy, 2001) and subject to changes triggered by teaching experience (Woodcock and Reupert, 2016). FL teacher self-efficacy in implementing inclusive instructional practices involves an ability to manage classroom environment, differentiate instruction, teaching content, tasks, assignments, modes of presentation, assessment and feedback techniques so that special educational needs of individual learners are met. It also refers to being able to help learners develop successful learning strategies and learner autonomy (Nijakowska et al., 2018). Teacher self-efficacy beliefs can influence both their attitudes to inclusion and their actual teaching practice. Teachers who believe they are less self-efficacious may show less commitment to teaching and persistence when facing difficulties (e.g. Malinen et al., 2012; Ozder, 2011; Sharma et al., 2012).

Positive attitude to inclusion involves recognizing the importance of individualised approach to teaching and the need for the educational system to be flexible enough to cater for the varied needs learners may have. Social 
encounters, direct contact and successful teaching experiences with special educational needs students can boost teachers' attitudes to inclusive education (Avramidis and Norwich, 2002). FL teachers who have more individualised and personalised teaching experience with dyslexic learners demonstrated higher levels of TEPID, in which attitude to inclusion constitutes an integral underlying factor (Nijakowska et al., 2018). Variables such as perceived school support for inclusive teaching practices can further raise teachers' attitudes to inclusion (Ahmmed et al., 2012).

Research referring to inclusive teaching practices with L2 dyslexic learners and foreign language teacher preparedness to include these learners in mainstream classes confirms that FL teachers believe they are poorly prepared for the task (Nijakowska et al., 2018). Importantly, professional teacher training proves effective in altering these beliefs in that it can lower FL teachers' reported concerns, boost their self-efficacy beliefs and attitudes towards inclusion (Kormos and Nijakowska, 2017). There exist pressing needs for the provision of appropriate and sufficient initial teacher training and continuing professional development opportunities for foreign language teachers in order to prepare them to appropriately recognize and respond to dyslexic L2 learners' needs (Nijakowska, 2014; Nijakowska et al., 2018).

\section{REFERENCES}

AHMMED, M.; SHARMA, U. \& DEPPELER, J. (2012): "Variables affecting teachers' attitudes towards inclusive education in Bangladesh", Journal of Research in Special Educational Needs, 12, pp. 132-140.

ALADWANI, A. M. \& AL SHAYE, S. S. (2012): "Primary school teachers' knowledge and awareness of dyslexia in Kuwaiti students", Education, 132 (3), pp. 499-516.

AVRAMIDIS, E. \& NORWICH, B. (2002): "Teachers' attitudes towards integration/inclusion: A review of the literature", European Journal of Special Needs Education, 17 (2), pp. 129-147.

APA (American Psychiatric Association) (2013): Diagnostic and statistical manual of mental disorders (5th edic.), Arlington, VA: American Psychiatric Association.
BANDURA, A. (1977): "Self-efficacy: Toward a unifying theory of behavioural change", Psychological Review, 84, pp. 191-215.

BRADY, S.; GILLIS, M.; SMITH, T.; LAVALETTE, M.; LISS-BRONSTEIN, L.; LOWE, E.; NORTH, W.; RUSSO E. \& WILDER, T. D. (2009): "First grade teachers' knowledge of phonological awareness and code concepts: Examining gains from an intensive form of professional development and corresponding teacher attitudes", Reading and Writing: An Interdisciplinary Journal, 4, pp. 425-455,

CHAO, C. N. G.; FORLIN, C. \& HO, F. C. (2016): "Improving teaching self-efficacy for teachers in inclusive classrooms in Hong Kong", International Journal of Inclusive Education, 20 (11), pp. 1142-1154. 
CSIZÉR, K.; KORMOS, J. \& SARKADI, A. (2010): "The dynamics of language learning attitudes and motivation: Lessons from an interview study of dyslexic language learners", The Modern Language Journal, 94, pp. 470487.

DE JONG, P. \& VAN DER LEIJ, A. (2003): "Developmental changes in the manifestation of a phonological deficit in dyslexic children learning to read in a regular orthography", Journal of Educational Psychology, 95, pp. 22-40.

ELLIOTT, J. G. \& GIBBS, S. (2008): "Does dyslexia exist?", Journal of Philosophy of Education, 42, pp. 475-491.

ELLIOTT, J. G. \& GRIGORENKO, E. L. (2014): The Dyslexia debate, New York: Cambridge University Press.

FAWCETT, A. J. \& NICOLSON, R. I. (2004): "Dyslexia: The role of the cerebellum", Reid G. \& Fawcett, A. J. (eds.): Dyslexia in context. Research, policy and practice, London: Whurr, pp. 25-47.

FLORIAN, L. (2012): "Preparing teachers to work in inclusive classrooms: Key lessons for the professional development of teacher educators from Scotland's inclusive practice project", Journal of Teacher Education, 63 (4), pp. 275-285.

FORLIN, C.; SHARMA, U. \& LOREMAN, T. (2014): "Predictors of improved teaching efficacy following basic training for inclusion in Hong Kong", International Journal of Inclusive Education, 18 (7), pp. 718-730.

FRITH, V. (1999): "Paradojas en la definición de la dyslexia", Dislexia, 5, pp. 192-194.

GANSCHOW, L. \& SPARKS, R. (2001): "Learning difficulties and foreign language learning: A re- view of research and instruction", Language Teaching, 34, pp. 79-98.

GENESEE, F.; GEVA, E.; DRESSLER, C. \& KAMIL, M. (2006): "Synthesis: Cross-linguistic relation-ships in working memory, phonological processes, and oral language", August, D. \& Shanahan, T. (eds.): Developing literacy in second-language learners: A report of the national literacy panel on language-minority children and youth, Mahwah, NJ: Erlbaum, pp. 153174.

GEVA, E. (2000): "Issues in the assessment of reading disabilities in L2 children beliefs and research evidence", Dyslexia, 6, pp. 13-28.

GEVA, E. \& RYAN, E. B. (1993): "Linguistic and cognitive correlates of academic skills in first and second languages", Language Learning, 43 (1), pp. 5-42.

GEVA, E. \& WIENER, J. (2015): Psychological assessment of culturally and linguistically diverse children and adolescents: A practitioner's guide, New York: Springer Publishing Company.

GOLDFUS, C. (2012): "Knowledge foundations for beginning reading teachers in EFL", Annals of Dyslexia, 62, pp. 204-221

GOSWAMI, U. (2000): "Phonological representations, reading development and dyslexia: Towards a cross-linguistic theoretical framework", Dyslexia, 6, pp. 133-151.

HELLAND, T. \& KAASA, R. (2005): "Dyslexia in English as a second language", Dyslexia, 11 (1), pp. 41-60.

HULME, C. \& SNOWLING, M. J. (2009): Developmental disorders of language learning and cognition, Oxford/Malden: Wiley-Blackwell. 
JOSHI, R. M.; BINKS, E.; HOUGEN, M.; DAHLGREN, M.; DEAN, E. \& SMITH, D. (2009): "Why elementary teachers might be inadequately prepared to teach reading", Journal of Learning Disabilities, 42, pp. 392-402.

KAHN-HORWITZ, J. (2015): "Organizing the mess in my mind: EFL teachers' perceptions and knowledge of English orthography", Reading and Writing: An Interdisciplinary Journal, 28, pp. 611-631.

KAHN-HORWITZ, J. (2016): "Providing English foreign language teachers with content knowledge to facilitate decoding and spelling acquisition: A longitudinal perspective", Annals of Dyslexia, 66, pp. 147-170.

KORMOS, J. (2017a): The second language learning processes of students with Specific Learning Difficulties, New York: Routledge.

KORMOS, J. (2017b): "The effects of Specific Learning Difficulties on processes of multilingual language development", Annual Review of Applied Linguistics, pp. 1-15.

KORMOS, J. \& CSIZÉR, K. (2010): “A comparison of the foreign language learning motivation of Hungarian dyslexic and nondyslexic students", International Journal of Applied Linguistics, 20, pp. 232-250.

KORMOS, J. \& NIJAKOWSKA, J. (2017): "Inclusive practices in teaching students with dyslexia: Second language teachers' concerns, attitudes and self-efficacy beliefs on a Massive Open Online Learning Course", Teaching and Teacher Education, 68, pp. 30-41.

KORMOS, J.; CSIZÉR, K. \& SARKADI, Á. (2009): "The language learning experiences of students with dyslexia: Lessons from an interview study", International Journal of Innovation in Language Learning and Teaching, 3 (2), pp. 115-130.

KOŠAK-BABUDER, M.; KORMOS, J.; RATAJCZAK, M. \& PIŽORN, K. (2019): "The effect of read-aloud assistance on the text comprehension of dyslexic and nondyslexic English language learners", Language Testing, 36 (1), pp. 51-75.

LANDERL, K.; RAMUS, F.; MOLL, K.; LYYTINEN, H.; LEPPÄNEN, P. H. T.; LOHVANSUU, K. \& SCHULTE-KÖRNE， G. (2013): "Predictors of developmental dyslexia in European orthographies with varying complexity", Journal of Child Psychology and Psychiatry, 54 (6), pp. 686-694.

MALINEN, O-P.; SAVOLAINEN, H. \& XU, J. (2012): "Beijing in-service teachers' self-efficacy and attitudes towards inclusive education", Teaching and Teacher Education, 28, pp. 526-534.

MARTIN, D. (ed.) (2013): Researching dyslexia in multilingual settings: Diverse perspectives, Bristol: Multilingual Matters.

MCCUTCHEN, D.; ABBOTT, R. D.; GREEN, L. B.; BERETVAS, S. N.; COX, S.; POTTER, N. S. \& GRAY, A. L. (2002): "Beginning literacy: Links among teacher knowledge, teacher practice, and student learning", Journal of Learning Disabilities, 35, pp. 69-86.

MCCUTCHEN, D.; GREEN, L.; ABBOTT, R. D. \& SANDERS, E. A. (2009): "Further evidence f or teacher knowledge: Supporting struggling readers in grades three through five", Reading and Writing: An Interdisciplinary Journal, 22, pp. 401-423. 
MILES, E. (2000): "Dyslexia may show a different face in different languages", Dyslexia, 6, pp. 193201.

MILLER-GURON, L. \& LUNDBERG, I. (2000): "Dyslexia and second language reading: A second bite at the apple?", Reading and Writing, 12 (1-2), pp. 41-61.

MOATS, L. C. (2009): "Knowledge foundations for teaching reading and spelling", Reading and Writing: An Interdisciplinary Journal, 22, pp. 379-399.

MOATS, L. C. \& FOORMAN, B. R. (2003): "Measuring teachers' content knowledge of language and reading", Annals of Dyslexia, 53, pp. 23-45.

MOLL, K.; RAMUS, F.; BARTLING, J.; BRUDER, J.; KUNZE, S.; NEUHOFF, N. \& LANDERL, K. (2014): "Cognitive mechanisms underlying reading and spelling development in five European orthographies", Learning and Instruction, 29, pp. 65-77.

NATIONAL INSTITUTE OF CHILD HEALTH (2002): Definition of dyslexia, Washington, DC: National Institute of Child Health and Human Development. Disponible en: https://dyslexiaida.org/definition-of-dyle-

xia/ (Fecha de consulta: 20/10/2018).

NICOLSON, R. I. (2001): "Developmental dyslexia: Into the future", Fawcett, A. J. (ed.): Dyslexia. theory and good practice, London: Whurr, pp. 1-35.

NICOLSON, R. I. \& FAWCETT, A. J. (2008): Dyslexia, learning, and the brain, Cambridge, MA: MIT Press.

NIJAKOWSKA, J. (2008): "An experiment with direct multisensory instruction in teaching word reading and spelling to Polish dyslexic learners of English", Kormos, J. \& Kontra, E. H. (eds.): Language learners with special needs: An international perspective, Bristol: Multilingual Matters, pp. 130-157.

NIJAKOWSKA, J. (2010): Dyslexia in the foreign language classroom, Bristol: Multilingual Matters.

NIJAKOWSKA, J. (2014): "Dyslexia in the European EFL teacher training context", Pawlak, M. \& Aronin, L. (eds.): Essential topics in applied linguistics and multilingualism, Heidelberg: Springer, pp. 129-154.

NIJAKOWSKA, J. (2016): "Developmental dyslexia", Östman, J-O. \& Verschueren, J. (eds.): Handbook of pragmatics, [HOP 20], Amsterdam/Philadelphia: John Benjamins. pp. 1-31. Handbook of Pragmatics Online

NIJAKOWSKA, J.; TSAGARI, D. \& SPANOUDIS, G. (2018): "English as a foreign language teacher training needs and perceived preparedness to include dyslexic learners: The case of Greece, Cyprus and Poland", Dyslexia, 24 (4), pp. 357-379.

NIJAKOWSKA, J. (2019): "Foreign language teachers' preparedness to cater for special educational needs of dyslexic learners", European Journal of Special Needs Education, 34 (2), pp. 189-203.

NORWICH, B. (2009): "How compatible is the recognition of dyslexia with inclusive education?", Reid, G. (ed.): The Routledge companion to dyslexia, London: Routledge, pp. 177-193.

OZDER, H. (2011): "Self-efficacy beliefs of novice teachers and their performance in the classroom", Australian Journal of Teacher Education, 36 (5), pp. $1-15$.

PALLADINO, P.; BELLAGAMBA, I.; FERRARI, M. \& CORNOLDI, C. (2013): "Italian children with dyslexia are also poor in reading English words, but accurate in reading English 
pseudowords", Dyslexia, 19 (3), pp. 165-177.

PEEBLES, J. L. \& MONDAGLIO, S. (2014): "The impact of direct experience on preservice teachers' self-efficacy for teaching in inclusive classrooms", International Journal of Inclusive Education, 18 (12), pp. 1321-1336.

PEER, L. \& REID, G. (eds.) (2016): Multilingualism, literacy and dyslexia. Breaking down barriers for educators, London: Routledge.

PIECHURSKA-KUCIEL, E. (2008): "Input, processing and output anxiety in students with symptoms of developmental dyslexia", Kormos, J. \& Kontra, E. H. (eds.): Language learners with special needs. An international perspective, Bristol: Multilingual Matters, pp. 86-109.

PFENNINGER., S. E. (2015): "MSL in the digital age: Effects and effectiveness of computer-mediated intervention for FL learners with dyslexia", Studies in Second Language Learning and Teaching, 5, pp. 109-133.

PODHAJSKI, B.; MATHER, N.; NATHAN， J. \& SAMMONS, J. (2009): "Professional development in scientifically based reading instruction: Teacher knowledge and reading outcomes", Journal of Learning Disabilities, 42, pp. 403-417.

RAMUS, F. (2004): "Neurobiology of dyslexia: A reinterpretation of the data", Trends in Neurosciences, 27 (12), pp. 720-726.

RAMUS, F. (2006): “Genes, brain, and cognition: A roadmap for the cognitive scientist", Cognition, 101, pp. 247-269.

RAMUS, F. (2014): "Should there really be a "Dyslexia debate'?", Brain: A Journal of Neurology, 137, pp. 3371-3374.
RAMUS, F.; ROSEN, S.; DAKIN, S. C.; DAY, B. L.; CASTELLOTE, J. M.; WHITE, S. \& FRITH, U. (2003): "Theories of developmental dyslexia: Insights from a multiple case study of dyslexic adults", Brain, 126, pp. 841-865.

RAMUS, F.; WHITE, S. \& FRITH, U. (2006): "Weighing the evidence between competing theories of dyslexia", Developmental Science, 9 (3), pp. 265-269

ROSE, J. (2009): Identifying and teaching children and young people with dyslexia and literacy difficulties. Disponible en: http://webarchive.natioalachives.gov.uk/20130321060616/ https://www.education.gov.uk/publications/eOrderingDownload/006592009DOM-EN.pdf (Fecha de consulta: 20/10/2018).

SAVOLAINEN, H.; ENGELBRECHT, P.; NEL, M. \& MALINEN, O-P. (2012): "Understanding teachers' attitudes and self-efficacy in inclusive education: Implications for pre-service and in-service teacher education", European Journal of Special Needs Education, 27 (1), pp. 51-68.

SCHNEIDER, E. \& CROMBIE, M. (2003): Dyslexia and foreign language learning, London: David Fulton Publishers.

SEYMOUR, P. H. K.; ARO, M. \& ERSKINE, J. M. (2003): "Foundation literacy acquisition in European orthographies", British Journal of Psychology, 94, pp. 143-174.

SHARMA, U. \& GEORGE, S. (2016): "Understanding teacher self-efficacy to teach in inclusive classrooms", Garvis, S. \& Pendergast, D. (eds.): Asia-Pacific perspectives on teacher self-efficacy, Rotterdam: Sense Publishers, pp. 37-51. 
SHARMA, U. \& SOKAL, L. (2015): “The impact of a teacher education course on pre-service teachers' beliefs about inclusion: An international comparison", Journal of Research in Special Educational Needs, 15 (4), pp. 276284.

SHARMA, U.; LOREMAN, T. \& FORLIN, C. (2012): "Measuring teacher efficacy to implement inclusive practices", Journal of Research in Special Educational Needs, 12 (1), pp. 12-21.

SIEGEL, L. (2016): "Bilingualism and dyslexia: The case of children learning English as an additional language", Peer, L. \& Reid, G. (eds.): Multilingualism, literacy and dyslexia: Breaking down barriers for educators, London: Routledge, pp. 137147.

SMITH, A. M. (2008): “Teachers' and trainers' perceptions of inclusive education within TEFL certificate courses in Britain", Kormos, J. \& Kontra, E. H. (eds.): Language learners with special needs: An international perspective, Bristol, UK.: Multilingual Matters, pp. 214-234.

SNOWLING, M. J. (2001): "From language to reading and dyslexia", Dyslexia, 7 (1), pp. 37-46.

SNOWLING, M. \& HULME, C. (2012): "Annual Research Review: The nature and classification of reading disorders - a commentary on proposals for DSM-5", Journal of Child Psychology and Psychiatry, 53 (5), pp. 593-607.

SPARKS, R. (2013): "Individual differences in learning a foreign (second) language: A cognitive approach", Martin, D. (ed.): Researching dyslexia in multilingual settings: Diverse perspectives, Bristol: Multilingual Matters, pp. 36-54.

SPARKS, R. \& GANSCHOW, L. (1993): "The impact of native language learning problems on foreign language learning: Case study illustrations of the linguistic coding deficit hypothesis", Modern Language Journal, 77, pp. 58-74.

SPARKS, R.; GANSCHOW, L. \& PATTON, J. (2008): "L1 and L2 literacy, aptitude and affective variables as discriminators among high- and low-achieving L2 learners with special needs", Kormos, J. \& Kontra, E. H. (eds.): Language learners with special needs: An international perspective, Bristol: Multilingual Matters, pp. 11-35.

SPARKS, R.; PATTON, J.; GANSCHOW, L.; HUMBACH, N. \& JAVORSKY, J. (2006): "Native language predictions of foreign language proficiency and foreign language aptitude", Annals of Dyslexia, 56 (1), pp. 129-160.

TSAGARI, D. \& SPANOUDIS, G. (eds.) (2013): Assessing L2 students with learning and other disabilities, Newcastle upon Tyne: Cambridge Scholars Publishing.

TSAGARI, D. \& SPERLING, I. (2017): "Assessing SLLs with SpLDs: Challenges and opportunities for equity in education", Piechurska-Kuciel, E.; Szymańska-Czaplak, E. \& Szyszka, M. (eds.): At the crossroads: Challenges of foreign language learning, Cham: Springer International Publishing, pp. 175188.

TSCHANNEN-MORAN, M. \& WOOLFOLK HOY, A. (2001): "Teacher efficacy: Capturing an elusive construct", Teaching and Teacher Education, 17, pp. 783805.

TSCHANNEN-MORAN, M. \& WOOLFOLK HOY, A. (2007): "The differential antecedents of self-efficacy beliefs of novice and experienced teachers", Teaching 
and Teacher Education, 23, pp. 944-956.

VELLUTINO, F. R.; FLETCHER, J. M.; SNOWLING M. J. \& SCANLON, D. M. (2004): "Specific reading disability (dyslexia): What have we learned in the past four decades?", Journal of Child Psychology \& Psychiatry, 45, pp. 240.

WASHBURN, E. K.; JOSHI, R. M. \& BINKS-CANTRELL, E. S. (2011a): "Teacher knowledge of basic language concepts and dyslexia", Dyslexia, 17, pp. 165-183.

WASHBURN, E. K.; JOSHI, R. M. \& BINKS-CANTRELL, E. S. (2011b): “Are preservice teachers prepared to teach struggling readers?", Annals of Dyslexia, 61, pp. 21-43.

WOODCOCK, S. \& REUPERT, A. (2016): "Inclusion, classroom management and teacher selfefficacy in an Australian context”, Garvis, S. \& Pendergast,
D. (eds.): Asia-Pacific perspectives on teacher self-efficacy, Rotterdam: Sense Publishers, pp. 87-102.

ZIEGLER, J. C. \& GOSWAMI, U. (2005): "Reading acquisition, developmental dyslexia, and skilled reading across languages: A psycholinguistic grain size theory", Psychological Bulletin, 131, pp. 3-29.

ZIEGLER, J. C. \& GOSWAMI, U. (2006): "Becoming literate in different languages: Similar problems, different solutions", Developmental Science, 9 (5), pp. 426-453.

ZIEGLER, J.; PERRY, C.; MA-WYATT, A.; LADNER, D. \& SCHULTEKORNE, G. (2003): "Developmental dyslexia in different languages: Language-specific or universal?", Journal of Experimental Child Psychology, 86, pp. 169-193. 